\title{
How to Make Concrete More Sustainable
}

\author{
Harald Justnes ${ }^{1}$
}

\section{Abstract}

Production of cement is ranking $3^{\text {rd }}$ in causes of man-made carbon dioxide emissions world-wide. Thus, in order to make concrete more sustainable one may work along one or more of the following routes; 1) Replacing cement in concrete with larger amounts of supplementary cementing materials (SCMs) than usual, 2) Replacing cement in concrete with combinations of SCMs leading to synergic reactions enhancing strength, 3) Producing leaner concrete with less cement per cubic meter utilizing plasticizers and 4) Making concrete with local aggregate susceptible to alkali silica reaction (ASR) by using cement replacements, thus avoiding long transport of non-reactive aggregate.

\section{Introduction}

The cement industry world-wide is calculated to bring about $5-8 \%$ of the total global anthropogenic carbon dioxide $\left(\mathrm{CO}_{2}\right)$ emissions. The general estimate is about 1 tonne of $\mathrm{CO}_{2}$ emission per tonne clinker produced, if fossil fuel is used and no measures are taken to reduce it. The $3^{\text {rd }}$ rank is not because cement is such a bad material with respect to $\mathrm{CO}_{2}$ emissions, but owing to the fact that it is so widely used to construct the infrastructure and buildings of modern society as we know it. Concrete is actually among the more environmentally friendly materials since it is composed in general of about 1 part cement, 0.5 parts water and 5-6 parts of sand and gravel (i.e. aggregate). The world's cement production was roughly 2.7 billion tonnes in 2010 , meaning roughly 19 billion tonnes concrete or 8.6 billion $\mathrm{m}^{3}$ concrete. This quantity can be translated into making a concrete cylinder of $25 \mathrm{~cm}$ diameter reaching the moon and back to earth every day or a solid concrete block with about $1 \mathrm{~km}^{2}$ base reaching the height of Mount Everest!

A lot is done by cement producers to reduce the global carbon footprint, in particular to replace coal with waste having a calorific value equivalent to (fossil) fuel and by making blended cement where parts of the clinker is replaced with supplementary cementing materials (SCMs). However, cement is a bulk product that should cover a wide range of applications and serve different customers, giving limitations on clinker replacements.

Concrete, on the other hand, is the end product where the performance criteria are already specified and depending on application more can be done to increase its sustainability. This paper discusses the potential achievements and challenges by

1. Replacing cement in concrete with larger amounts of

${ }^{1}$ Chief Scientist, SINTEF Building and Infrastructure, Trondheim, Norway.

E-mail: harald.justnes@sintef.no
SCMs, also uncommon ones like calcined marl

2. Replacing cement in concrete with combinations of SCMs leading to synergic reactions enhancing strength

3. Producing leaner concrete with less cement per cubic meter utilizing plasticizers.

4. Making concrete with local aggregate susceptible to alkali silica reaction (ASR) by using cement replacements, thus avoiding long transport of nonreactive aggregate

Other aspects adding to more sustainable use of concrete is not a part of this paper, like;

5. Making concrete with recycled aggregate from demolished concrete structures.

6. Making more durable concrete with less maintenance and longer service life.

7. Making slimmer structures with high strength concrete. More cement per cubic meter, but less cubic meters

8. Utilizing the heat capacity of bare concrete to save energy for heating/cooling of offices/housing

\section{Concrete with high content of SCM}

Replacing parts of the cement in concrete with SCMs, or making blended cement where clinker is partly replaced with SCMs, is the fastest short term remedy to reduce $\mathrm{CO}_{2}$ emissions from the cement and concrete industry. Blast furnace slags as latent hydraulic SCMs or pozzolana consuming calcium hydroxide; e.g. fly ash, are the most common ones. Limestone powder is also used as filler, in particular in self-compacting concrete. In Europe most granulated blast furnace slag is put into good use, and high quality fly ash is becoming scarce in some areas. Other pozzolana used in smaller dosages, but often in combination with others, are silica fume, rice husk ash and metakaoline. However, the latter ones are not available in sufficiently large amounts, or are too expensive, to have large impacts on lowering $\mathrm{CO}_{2}$ emissions, even though they are contributing. Thus, there has been a search for large volumes of unexploited resources and one possibility found is calcareous clay or 
marl unsuitable for clay industries producing brick or light weigh aggregate (LWA). Since common blue clay is so abundant, this may also be a viable option. Both common blue clay and marl will have to be calcined at $750-850^{\circ} \mathrm{C}$ prior to use as pozzolana. Be aware when using clays that they can contain chlorides if they originate from marine deposits, so the chloride content must always be checked prior to use in reinforced concrete.

Justnes et al. (2011a) tested calcined blue clay as a stabilizer for SCC (self-compacting concrete) by replacing limestone filler. As can be seen from Fig. 1, increasing clay replacement increased yield stress while the viscosity was relatively stable. In addition, the compressive strength increased with increasing clay replacement at all ages tested as depicted in Fig. 2. The starting point was $30 \mathrm{vol} \%$ limestone filler and then $1 / 3$ and $2 / 3$ of this was replaced with calcined clay.

Calcined marl as an effective pozzolan was published by Justnes et al. (2011b). Compressive strengths of mortar where cement was partly replaced with marl calcined in pilot scale rotary kiln as a function of curing age is plotted in Fig. 3. Note that same strength as reference is obtained at 28 days and sufficient strength $(\approx 10 \mathrm{MPa})$ for demoulding at 1 day when cured at $20^{\circ} \mathrm{C} / 90 \% \mathrm{RH}$.

The compressive strengths of mortar with cement partly replaced by marl calcined in full scale (industrial) rotary kiln as function of replacement level and age is published by Østnor and Justnes (2013) together with durability properties of the same mortars.

When large amounts of cement are to be replaced by SCMs, the challenge is usually rather low early strength that might be needed to be boosted in order to maintain productivity or construction rate. This can either be done by mechanical or chemical activation as described in the proceeding.

\subsection{Mechanical activation}

\subsubsection{Introduction}

While ordinary grinding will increase the fineness and thereby the reactivity by increasing the surface area where reaction can take place (De Weerdt et al. 2011), mechanical activation is thought to change the surface of the solid material on a molecular level enhancing its reactivity. Such a measure to enhance early strength can be energetic modification by special grinding as for Energetically Modified Cement (EMC; www.emccement.com) extensively studied from the beginning of 1990 s produced by high intensive grinding/activation of ordinary Portland cement (OPC) together with different types of fillers; e.g. Justnes et al. (2005, 2007a).

\subsubsection{Energy modified cement (EMC) with quartz}

Justnes et al. (2007b) studied EMC produced with 20 (EMC-20) and 50\% (EMC-50) quartz rich (73.9\% $\mathrm{SiO}_{2}$ ) mine tailing replacing cement. The EMC process consists of a series of different mills also involving high

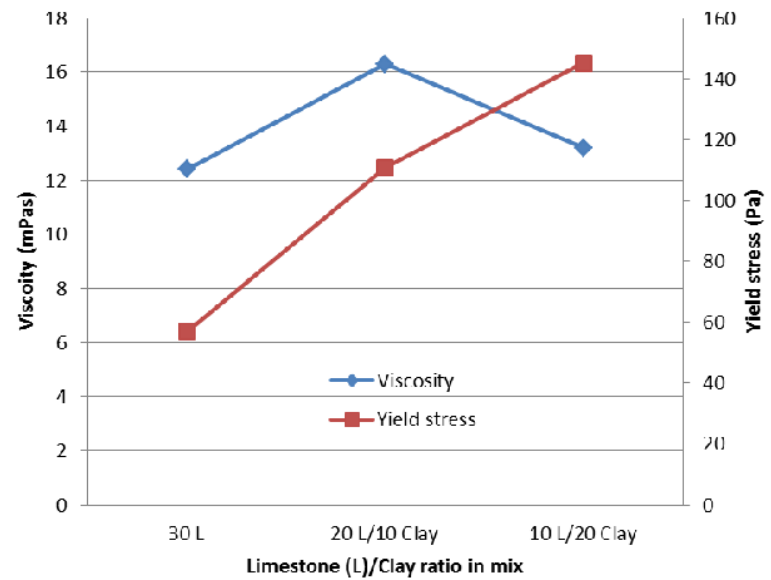

Fig. 1 The viscosity and yield stress of SCC where limestone powder $(L)$ is increasingly replaced by calcined blue clay (Clay) from Justnes et al. (2011a).

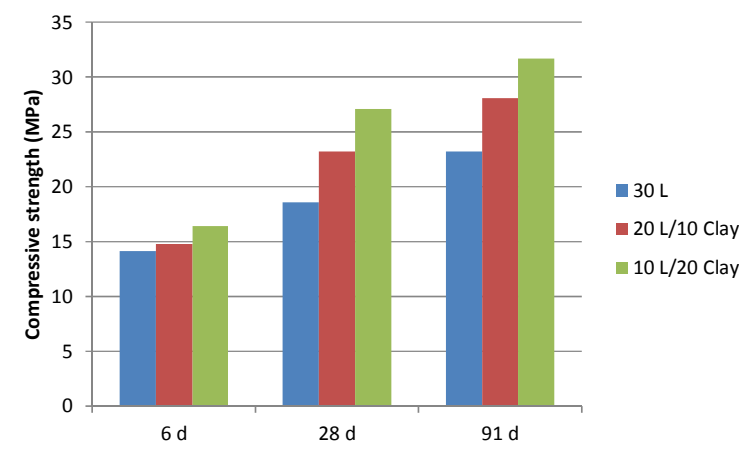

Fig. 2 Compressive strength evolution of SCC where limestone powder $(\mathrm{L})$ is replaced by calcined blue clay (Clay) from Justnes et al. (2011a).

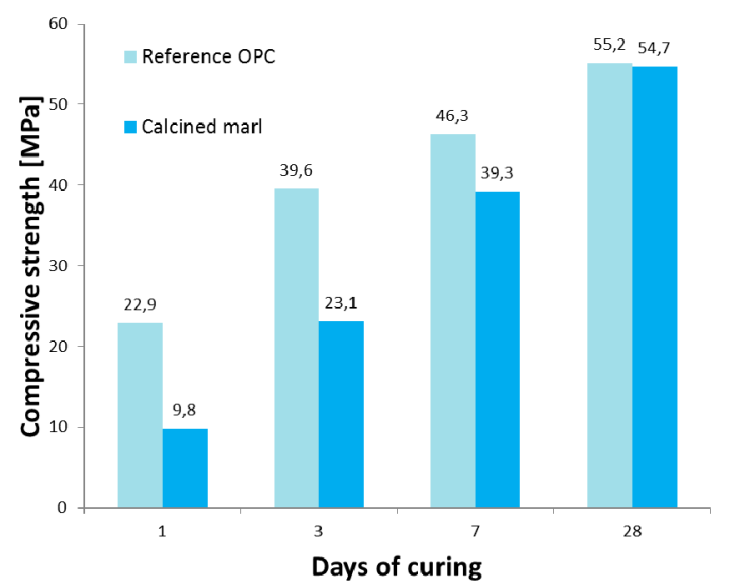

Fig. 3 Compressive strength of mortars with 0 (reference) and $50 \%$ replacement of cement by calcined marl cured for 1, 3, 7 and 28 days (Justnes et al. 2011b).

shear energy. The properties of the concrete are presented in Table 1. Evidently concrete with EMC-50 is not significantly different from the OPC used to make it with respect to the important fresh concrete properties like workability, stability, air content and setting time. However, the dosage of superplasticizer (Mighty 150, $40 \%$ solution) needed to produce the required consis- 
Table 1 Properties of fresh concrete.

\begin{tabular}{|c|c|c|c|c|c|}
\hline \multirow{2}{*}{ BinderType } & \multirow{2}{*}{ w/b } & \multicolumn{2}{|c|}{$\begin{array}{c}\text { Consistency, } \\
\mathrm{mm}\end{array}$} & \multirow{2}{*}{$\begin{array}{c}\text { App. Density } \\
\mathrm{kg} / \mathrm{m} 3\end{array}$} & $\begin{array}{c}\text { Air } \\
\text { vol. \% }\end{array}$ \\
\cline { 2 - 4 } & & Slump & Spread & & \\
\hline \multirow{3}{*}{ OPC } & 0.45 & 110 & 420 & 2,420 & 2.0 \\
\cline { 2 - 6 } & 0.50 & 90 & 390 & 2,410 & 2.2 \\
\cline { 2 - 4 } & 0.60 & 105 & 425 & 2,400 & 2.1 \\
\hline \multirow{3}{*}{ EMC-50 } & 0.45 & 85 & 395 & 2,380 & 2.1 \\
\cline { 2 - 4 } & 0.50 & 90 & 390 & 2,390 & 1.9 \\
\cline { 2 - 4 } & 0.60 & 80 & 370 & 2,400 & 1.5 \\
\hline
\end{tabular}

tency at each w/b-ratio (water-to-binder ratio, assuming the quartz in this case to be part of binder) was somewhat higher for the EMC mixes than for the OPC reference mixes. The EMC-50 generated a total heat per unit weight equal to the heat of the reference OPC cement liberation, which in combination with the strength development (Fig. 4 and 5) of EMC concrete, indicates significant chemical activation of the Portland clinker and possibly quartz components in EMC as indicated by calcium hydroxide content for paste specimens stored for 950 days (Justnes et al. 2007b). A bridge made by EMC with $50 \%$ quartz was actually built as a feasibility demonstration in 1998 in Sweden.

The compressive strength development of OPC and EMC-50 concrete in Fig. $\mathbf{4}$ and $\mathbf{5}$ demonstrates slightly lower early age strengths ( 1 and 2 days curing time) for EMC and this difference is more pronounced with increased w/b. EMC reached compressive strength equal to OPC at about 7 days of hardening and exhibited strength superior to OPC concrete after 28 and 90 days reaching strength levels of $\approx 40 \mathrm{MPa}$ and $70 \mathrm{MPa}$ for $\mathrm{w} / \mathrm{b}=0.60$ and 0.45 , respectively.

The effective diffusion coefficients according to NTBuild 443 are for OPC and EMC plotted as a function of w/b in Fig. 6. The EMC concrete showed a considerably higher resistance to chloride penetration relative to the OPC concrete at similar w/b. Chloride diffusion coefficients of EMC concrete are significantly lower relative to OPC concrete, especially with increased $w / b$. For $w / b=0.60$ the diffusion coefficients for EMC are only $50 \%$ of the coefficients for OPC concrete. Concrete produced with EMC containing 20\% and $50 \%$ of quartz filler by OPC replacement showed comparable levels for diffusion coefficients.

\subsubsection{Energy modified cement with fly ash}

Justnes et al. (2007c) showed that it is feasible to make an EMC with $30 \%$ fly ash with 1 day strength of 37 $\mathrm{MPa}$ as opposed to $5 \mathrm{MPa}$ for a blend for the same components and $10 \mathrm{MPa}$ for an OPC. EMCs with 50 and $70 \%$ replacement of cement by fly ash had 1 day strengths of 15 and $11 \mathrm{MPa}$, respectively, which should be sufficient for form work removal and ensure the usual construction progress.

Table 2 reveals the detailed data (Justnes et al. 2007c) for water demand and the compressive strength development of mortars based on EMC cement (30, 50 and $70 \% \mathrm{FA}$ ) in comparison with standard Portland ce-

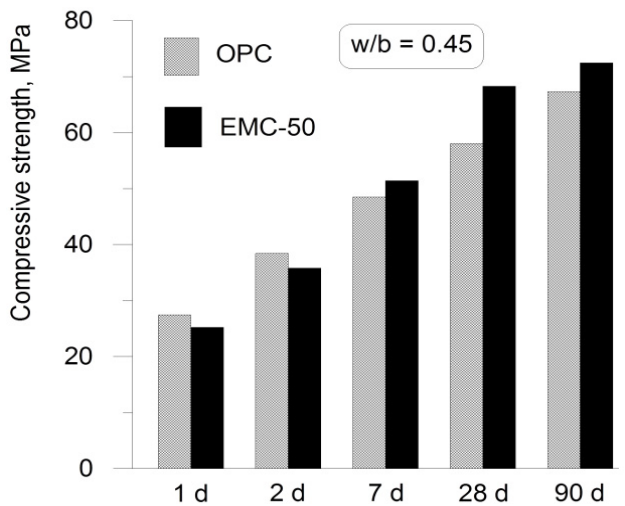

Fig. 4 Compressive strength (100 mm cube) of concrete with $w / b=0.45$ according to ISO 4012 .

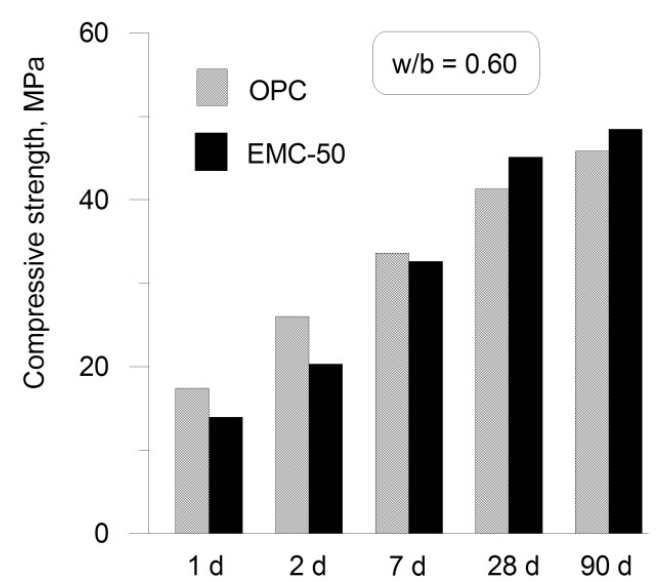

Fig. 5 Compressive strength (100 mm cube) of concrete with $w / b=0.60$ according to ISO 4012 .

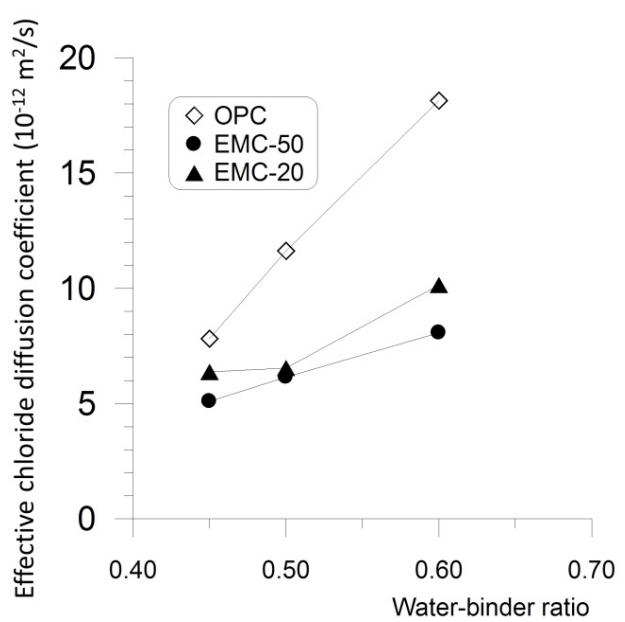

Fig. 6 Effective chloride diffusion coefficient in accordance with NTBuild 443 for OPC and EMC as a function of $w / b$.

ment and standard Portland cement with 20 and $40 \%$ of replacement with FA that has not been subjected to the EMC process (reference blends). EMC with $30 \%$ fly ash and water-to-binder ratio $(\mathrm{w} / \mathrm{b}$, where fly ash is part of the binder) 0.40 can be considered as high strength / 
Table 2 Compressive Strength Development (MPa) of concrete with equal flow.

\begin{tabular}{|l|c|c|c|c|c|}
\hline \multirow{2}{*}{\multicolumn{1}{|c|}{ Cement type }} & \multirow{2}{*}{ w/b } & \multicolumn{4}{|c|}{ Curing time (days) } \\
\cline { 3 - 6 } & & 1 & 3 & 7 & 28 \\
\hline OPC $^{1}$ & 0.48 & 10.3 & 26.6 & 30.0 & 38.6 \\
EMC $\left(50 \%\right.$ FA) $^{1}$ & 0.43 & 14.7 & 22.9 & 27.2 & 41.1 \\
EMC $\left(30 \%\right.$ FA) $^{1}$ & 0.40 & 36.7 & - & 51.6 & 62.4 \\
EMC $\left(70 \%\right.$ FA) $^{2}$ & 0.42 & 11.0 & 23.0 & 28.0 & - \\
EMC $\left(70 \%\right.$ FA) $^{2}$ & 0.38 & 12.5 & 23.4 & 30.0 & - \\
$80 \%$ OPC $^{1}+20 \%$ FA & 0.46 & 6.5 & 20.4 & 23.6 & 35.8 \\
60\% OPC $^{1}+40 \%$ FA & 0.44 & 3.8 & 15.1 & 17.7 & 29.6 \\
\hline
\end{tabular}

${ }^{1}$ OPC from Texas, USA. ${ }^{2}$ OPC (CEM I 42,5) from Sweden

high performance alternative for the newly developed blended cements, while $70 \%$ FA replacement may consider a high performance HVFA (high volume fly ash) cement.

According to Table 2, the EMC cement made by $50 \%$ OPC and 50\% FA gave about 40\% higher strength after 24 hours than the reference OPC. This EMC mortar had slightly lower compressive strength than OPC mortar at 7 days, but was superior to OPC mortar after 28 days. The EMC (50\% FA) performed significantly better than Portland-pozzolan blended cements with $20 \%$ and $40 \%$ fly ash replacements. The workability of this EMC appears better than the OPC. The high fly ash content in combination with optimized particle size distribution allows $10 \%$ reduction in $\mathrm{w} / \mathrm{b}$, which along with the increased reactivity of FA contributes to higher long-term strength. The EMC based on $30 \% \mathrm{FA}$ and $70 \%$ of OPC showed a compressive strength development in line with rapid hardening Portland cement and gave a 28 days flexural strength of 9.6 MPa. The setting time of HVFA EMC ( $70 \%$ FA) is in line with OPC; initial and final set $2 \mathrm{~h} 40 \mathrm{~min}$ and $3 \mathrm{~h} 50 \mathrm{~min}$, respectively. No water reducing agent has been used for the mortar with $\mathrm{w} / \mathrm{b}=0.42$ in Table 2 . It had $10-12 \%$ higher flow than OPC mortar with same water content. HVFA EMC is very sensitive to addition of superplasticizer. Only $0.1 \%$ by mass of cementitious material $(\mathrm{cm}=\mathrm{OPC}+\mathrm{FA})$ leads to a reduction of $\mathrm{w} / \mathrm{b}$ from 0.42 to 0.38 while maintaining flow. Mortars with HVFA exhibit excellent surfaces without flaws. According to Table 2, HVFA EMC shows improved 1 day strength and comparable 7 days strength to OPC mortar of comparable flow.

\subsection{Chemical Activation}

Both GGBS (ground, granulated blast-furnace slag) and FA (fly ash) are activated by increased $\mathrm{pH}$, but while GGBS is a latent hydraulic material, FA is a pozzolanic material consuming calcium hydroxide in producing hydraulic binder.

One advantage of using common potassium carbonate $\left(\mathrm{K}_{2} \mathrm{CO}_{3}\right.$ or $\mathrm{KC}$ in short), or sodium carbonate $\left(\mathrm{Na}_{2} \mathrm{CO}_{3}\right.$ or $\mathrm{NC}$ in short) for that matter as fly ash or slag activator, is that they are safe to handle and will form high $\mathrm{pH}$ in situ by reaction with calcium hydroxide from cement hydration;

$$
\mathrm{CH}+\mathrm{K} \underline{\mathrm{C}}=\mathrm{C} \underline{\mathrm{C}}+\mathrm{KH}
$$

and at the same time form calcium carbonate with high surface area that probably is faster reactive with calcium aluminate hydrates than limestone powder. Such in situ forming accelerators were utilized by Justnes (1995, 1996) making lime-pozzolan mortars with high early strength. The disadvantage may be that alkali carbonates may retard the setting of cement too much and give somewhat lower long term strength depending on total alkali content.

Sodium sulphate is also a good accelerator for aluminate containing pozzolana and slag involving in situ formation of $\mathrm{NaOH}$ for further acceleration and formation of solid ettringite and/or monosulphate with increased water binding;

$$
\begin{aligned}
& 3 \mathrm{~N} \underline{\mathrm{S}} \text { (low pH) }+3 \mathrm{CH} \text { (from cement) }+ \\
& \mathrm{C}_{3} \mathrm{AH}_{6} \text { (from pozzolan) }+26 \mathrm{H}= \\
& 3 \mathrm{NH} \text { (high pH) }+\mathrm{C}_{6} \underline{\mathrm{A}}_{3} \mathrm{H}_{32}
\end{aligned}
$$

Shi and Day (1995, 2000a, b, 2001) studied the effect of $\mathrm{Na}_{2} \mathrm{SO}_{4}$ and $\mathrm{CaCl}_{2}$ as chemical activators on the strength of lime-fly ash pastes. Two different fly ashes were used (LFA=low lime content and $\mathrm{HFA}=$ high lime content) in the $20 \%$ hydrated lime and $80 \%$ fly ash mixes (no cement) and the chemical activators were added in dosages up to $5 \%$ of the lime-fly ash mass. The pastes were prepared with a water/solid ratio of 0.35 (LFA) or 0.375 (HFA), and cured moist at $50^{\circ} \mathrm{C}$. Both $\mathrm{Na}_{2} \mathrm{SO}_{4}$ and $\mathrm{CaCl}_{2}$ clearly increased the compressive strength of the mortars, but sodium sulphate was superior with respect to the 1 day strength. Unfortunately are many of the chemical activation experiments performed at elevated temperatures being irrelevant for ready mix concrete, but still applicable for precast concreting.

Qian et al. (2001) compared the effect of grinding for 30 minutes in a ball mill and chemical activation through the addition of $3-4 \% \mathrm{Na}_{2} \mathrm{SO}_{4}$. They found that chemical activation was more efficient than ordinary grinding. Chemical activation increased the 3 and 7 daystrength of cement replaced with $30 \%$ fly ash by $5-10$ $\mathrm{MPa}$.

Lee et al. (2003) studied the strength and microstructure of fly ash-cement systems containing the accelerators sodium sulphate, potassium sulphate and triethanolamine. The accelerators did not only decrease or maintain the amount of calcium hydroxide, but also increased the amount of ettringite at early ages. The authors felt that small dosages of these accelerators were a viable solution for increasing the early compressive strength of concrete with high amounts of fly ash.

However, Hoang (2012) showed that it was possible to increase the strength of mortar where cement has been replaced by $30 \%$ fly ash by $60 \%$ after 2 days at $5^{\circ} \mathrm{C}$ and by $30 \%$ after 1 day at $20^{\circ} \mathrm{C}$ using a ternary accelerator at a dosage of only $0.35 \%$ of cement/fly ash mass. 


\section{Concrete with ternary binders}

Limestone is widely available and either used as raw meal for clinker making or as filler either in cement or in concrete. Fly ash from coal fired energy plants is abundant in India and many other countries. Combining fly ash with limestone will give a strength increase as a result of a chemical synergy. The theoretical consideration of combining limestone and siliceous fly ash is as follows using cement chemist's shorthand notation where $\mathrm{C}=\mathrm{CaO}, \mathrm{S}=\mathrm{SiO}_{2}, \mathrm{~A}=\mathrm{Al}_{2} \mathrm{O}_{3}, \mathrm{~F}=\mathrm{Fe}_{2} \mathrm{O}_{3}, \underline{\mathrm{S}}=$ $\mathrm{SO}_{3}, \underline{\mathrm{C}}=\mathrm{CO}_{2}$ and $\mathrm{H}=\mathrm{H}_{2} \mathrm{O}$ :

In an ordinary Portland cement the limestone filler is often considered inert since it has so little calcium aluminate hydrate to react with. The early $\mathrm{C}_{3} \mathrm{~A}$ (usually 2$10 \%$ of cement mass) reaction with gypsum initially lead to Ettringite $\left(\mathrm{C}_{6} \mathrm{AS}_{3} \mathrm{H}_{32}\right)$, but there is normally not enough gypsum $\left(\mathrm{CS}_{2}\right)$ to balance all $\mathrm{C}_{3} \mathrm{~A}$, so when the $\mathrm{C}_{3} \mathrm{~A}$ continue to hydrate it will transform Ettringite to so called "monosulphate", or more correctly calcium monosulphoaluminate hydrate $\left(\mathrm{C}_{4} \mathrm{AS}_{12}\right)$;

$$
2 \mathrm{C}_{3} \mathrm{~A}+\mathrm{C}_{6} \mathrm{~A}_{3} \mathrm{H}_{32}+4 \mathrm{H}=3 \mathrm{C}_{4} \mathrm{AS}_{12}
$$

However, over time the "monosulphate" is unstable in presence of limestone and will form calcium carboaluminate hydrate $\left(\mathrm{C}_{4} \mathrm{~A} \underline{\mathrm{C}} \mathrm{H}_{11}\right)$ and the released sulphate may then react with "monosulphate" to form Ettringite again, which is stable in presence of limestone (Matschei et al., (2007a,b,c);

$$
2 \mathrm{C} \underline{\mathrm{C}}+3 \mathrm{C}_{4} \mathrm{AS}_{12}+18 \mathrm{H}=2 \mathrm{C}_{4} \mathrm{ACH}_{11}+\mathrm{C}_{6} \mathrm{AS}_{3} \mathrm{H}_{32} \text { (4) }
$$

According to Eq. 4, $100 \mathrm{~g}$ (=1 mole) of calcium carbonate $(\mathrm{C} \underline{\mathrm{C}})$ will bind $18 / 2=9$ mole $(162 \mathrm{~g})$ of extra liquid water, while cement binds $23 \mathrm{~g}$ water per $100 \mathrm{~g}$ reacted cement as comparison. Taking into account molar masses and densities of the individual compounds, the total increase in volume of solids for Eq. 4 can be calculated to $23 \mathrm{vol} \%$.

If there was even more $\mathrm{C}_{3} \mathrm{~A}$ in the cement, another stable phase after the hydration would have been calcium aluminate hexahydrate $\left(\mathrm{C}_{3} \mathrm{AH}_{6}\right)$ that also can react with limestone to form calcium carboaluminate hydrate;

$$
\mathrm{C} \underline{\mathrm{C}}+\mathrm{C}_{3} \mathrm{AH}_{6}+5 \mathrm{H}=\mathrm{C}_{4} \mathrm{ACH}_{11}
$$

According to Eq. 5, $100 \mathrm{~g}$ calcium carbonate $(1 \mathrm{~mol})$ would then bind $90 \mathrm{~g}(5 \mathrm{~mol})$ extra water. The total increase in volume of solids according to Eq. 5 is then 40 vol\%. So the replacement of cement with limestone would have been very efficient in lowering total porosity had there only been more calcium aluminate hydrate in the system. Increasing the $\mathrm{C}_{3} \mathrm{~A}$ is not a viable option, due to more sulphate required to control setting and thereby more initial Ettringite formation possibly hampering packing or flow. Calcium aluminate hydrates may, on the other hand, be produced after setting by aluminate containing supplementary cementing materials (e.g. slag, fly ash, metakaoline).
Usually, more limestone is added to cement than what can react with the aluminates present in the cement, even when one take into account hydration of the ferrite phase $\left(\mathrm{C}_{4} \mathrm{AF}\right)$. A Portland cement containing for instance $5 \% \quad \mathrm{Al}_{2} \mathrm{O}_{3}$ could only in theory consume $5 \% \cdot 100 / 102 \approx 5 \%$ calcium carbonate (using the molar ratio 1 from Eq. 5 and the molar weights 100 and 102 $\mathrm{g} /$ mole for $\mathrm{CaCO}_{3}$ and $\mathrm{Al}_{2} \mathrm{O}_{3}$, respectively) if all the aluminate was converted to calcium carboaluminate hydrate, which is not the case since a fraction of it will end up as stable Ettringite (see Eq. 4). Lothenbach et al. (2008) used thermodynamic modelling to calculate the phase assembly and porosity of cement with limestone and found good correlations with strength evolution.

Making cement with unusual high $\mathrm{C}_{3} \mathrm{~A}$ content would eventually make it difficult to control in terms of setting. Another possibility is to combine limestone with supplementary cementing materials (SCMs) that will form calcium aluminate hydrates in their reaction as already pointed out. Siliceous fly ash consisting of a glassy aluminosilicate (AS) phase forms a mixture of calcium silicate hydrate $(\mathrm{CSH})$ gel, Strätlingite $\left(\mathrm{C}_{2} \mathrm{ASH}_{8}\right)$ and calcium aluminate hydrates (e.g. $\mathrm{C}_{3} \mathrm{AH}_{6}$ ) in reaction with calcium hydroxide $(\mathrm{CH})$. The following pozzolanic reaction is unbalanced since there are too many unknowns;

$$
\mathrm{CH}+\mathrm{AS}+\mathrm{H} \rightarrow \mathrm{CSH}+\mathrm{C}_{2} \mathrm{ASH}_{8}+\mathrm{C}_{3} \mathrm{AH}_{6}
$$

When combining limestone powder and fly ash, the advantage of one component can compensate for the shortcomings of the other. Limestone powder can compensate by its filler effect for the loss of early age strength caused by the fly ash. Fly ash on the other hand can compensate by its pozzolanic reaction for the loss of long term strength caused by dilution effect of the limestone addition.

De Weerdt and Justnes (2008) studied fly ash - limestone - calcium hydroxide mixes prepared with a high alkaline solution $(\mathrm{pH}=13.2)$. A clear interaction between fly ash and limestone powder was observed. More water was bound relative to the fly ash content and the hydration products formed were altered. The calcium aluminate hydrates formed during the pozzolanic reaction of fly ash reacted with the calcium carbonate of the limestone powder and formed calcium carboaluminate hydrates. The interaction between the calcium carbonate of the limestone powder and the aluminate phase of clinker has been investigated by several researchers (Kuzel and Pölmann 1991; Kakali et al. 2000; Bonavetti et al. 2001; Lothenbach et al. 2008b). In the presence of small amounts of limestone powder, hydration products alter. This can cause the total volume of the hydration products to increase (Hirao et al. 2007; Matschei et al. 2007b;Lothenbach et al. 2008a) resulting in an increase in strength and a decrease in permeability. The effect of this interaction in OPC is however not so pronounced due to the limited aluminate content. Fly ash on the other hand can have relatively high alu- 
minate content. The chemical interaction between calcium aluminate hydrates and calcium carbonate might therefore be of greater importance in cement with high fly ash content or other SCMs leading to increased amounts of calcium aluminate hydrates.

This means that fly ash and limestone powder not only compensate for each other's shortcomings when it comes to short- and long-term strength (i.e. additive effect), but there is also a true chemical interaction between the calcium carbonate of the limestone and the calcium aluminate hydrates formed by the pozzolanic reaction (i.e. a synergic reaction) as now thoroughly documented by De Weerdt et al. (2011).

De Weerdt and Justnes (2008) showed that limestone will react with the pozzolanic product of fly ash to form calcium carboaluminate hydrate and also that this reaction contributes to strength (De Weerdt et al., 2010). Fig. 7 from the latter study shows that 5\% limestone in combination with $30 \%$ fly ash replacement of Portland gives higher 28 day strength that with $35 \%$ fly ash replacement alone, and even higher than $30 \%$ fly ash replacement only (marked with a square). This means that $5 \%$ limestone in this case has the same effect on strength as $5 \%$ cement!

The preceding synergic principle will probably work for limestone in combination with other SCMs producing calcium aluminate hydrates in their reaction; e.g. blast furnace slag, metakaolin and calcined blue clay as indicated by the results in Fig. 2. Calcined marl is a natural combination of calcined clay and calcium carbonate providing it is calcined below $900^{\circ} \mathrm{C}$ (decomposition temperature of calcite). The synergic reactions between the calcined clay part and the remaining calcium carbonate may contribute to the excellent strength documented in Fig. 3 when calcined marl replaces cement. Research on marl as a relatively new SCM will continue within the research program COIN (www.coinweb.no).

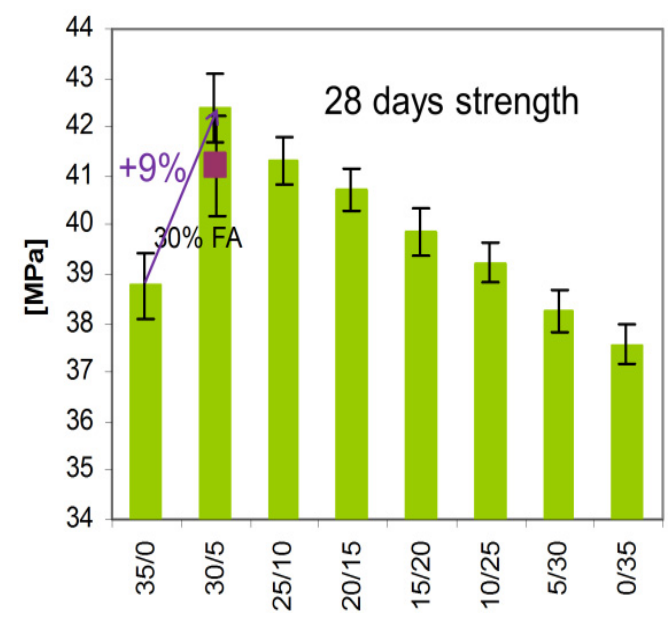

Fig. 7 Comparing the 28 day compressive strength of composite cements with different combination of fly ash (FA) and limestone powder (L).

\section{Making leaner concrete}

The principal different ways of using plasticizers or water reducing admixtures (WRAs) in concrete technology is sketched in Fig. 8. However, the most sustainable way is to save cement and water while maintaining strength and workability relative to reference without WRA.

Most concrete producers use WRA to save cement for economic reasons, but at the same time it gives ecological benefits towards more sustainable construction. As a rule of thumb with modern polycarboxylate based superplasticizers (PCS); $1 \mathrm{~kg}$ PCS reduces $20 \mathrm{~kg}$ water per $\mathrm{m}^{3}$ concrete. Using this rule for a concrete recipe with $350 \mathrm{~kg}$ cement and $1.8 \mathrm{~kg} \mathrm{PCS} / \mathrm{m}^{3}$ and keeping $\mathrm{w} / \mathrm{c}=$ 0.60 constant, means then $290 \mathrm{~kg}$ cement (i.e. $60 \mathrm{~kg}$ or $17 \%$ cement saved). Similar calculations can be done for any WRA knowing how many litre water can be saved per kg WRA (often stated by the admixture producer). The recipe is often economically optimized by having cement and water to a slump of $30 \mathrm{~mm}$ and then adding WRA to obtain a $200 \mathrm{~mm}$ slump.

Collepardi (2007) showed experimentally that the rule of thumb above is valid as reproduced in Table 3 .

Table 3 Recipe example with reduced binder utilizing WRA from Collepardi (2007).

\begin{tabular}{|l|ll|}
\hline Component $\left(\mathrm{kg} / \mathrm{m}^{3}\right)$ & Reference & WRA-mix \\
\hline CEM II A-V 42,5 N & 350 & $297(-15 \%)$ \\
0-4 mm sand & 915 & 982 \\
4-16 mm gravel & 395 & 424 \\
16-32 mm gravel & 483 & 519 \\
Water & 210 & 178 \\
WRA (PCS) & - & 1.8 \\
\hline Property & & \\
\hline w/c & 0.60 & 0.60 \\
aggregate/cement & 5.1 & 6.5 \\
slump (mm) & 230 & 240 \\
strength at 28 d (MPa) & 36 & 37 \\
\hline
\end{tabular}

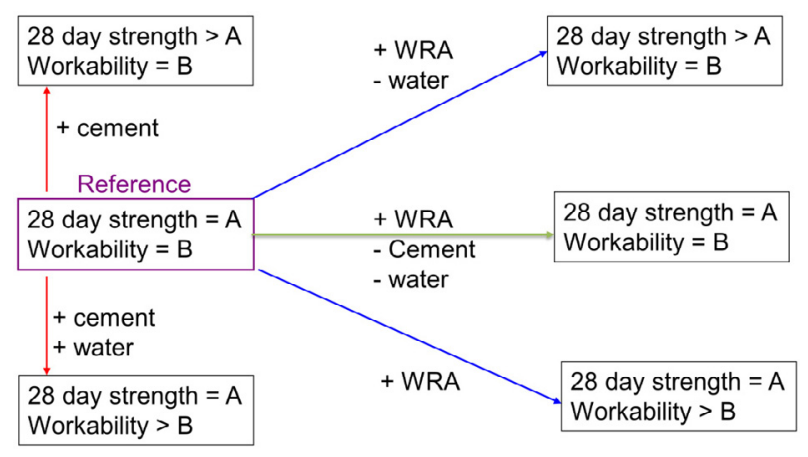

Fig. 8 A sketch of different ways of utilizing water reducing agents (WRA) in concrete technology from Rixom and Mailvaganam (1999). 


\section{Concrete with binders tolerating alkali- reactive aggregate}

The immediate conversion of alkali hydroxides to silicates by silica fume (SF) will result in reduced alkali aggregate reactions. However, Bérubé and Duchesne (1992) showed that SF merely postpones expansion due to AAR. Nevertheless, SF as a remedy against AAR, together with other improvements in construction procedures, has found its application in Iceland where all cement has been interground with 7-8 \% CSF to combat the problem (Asgeirsson 1986). In Norway, the cement is interground with $20 \%$ siliceous fly ash in order to be able to use ASR prone aggregate. Such solutions will contribute to more sustainable solutions as long transport of high quality aggregate is avoided and high quality deposits will last longer.

\section{Conclusions}

Concrete can never be made sustainable since it is based on non-renewable mineral resources. However, concrete can be made more sustainable (or less un-sustainable) by replacing cement with supplementary cementing materials based on industrial by-products like slag and fly ash.

Larger amount of fly ash can be used if loss in early strength is counteracted by finer grinding or special grinding (mechanical activation) or accelerators.

Cement with interground silica fume and/or fly ash can even allow the use of alkali reactive aggregate and further save environment (i.e. local deposits and less transport).

New SCMs like calcined blue clay or marl can replace fly ash in areas where high quality fly ash becomes scarce or are unavailable (other than by long transport).

Water reducing agents can be used to make concrete with less overall binder and same strength and workability, and thereby being more environmentally friendly.

Making more concrete with less cement clinker content means less $\mathrm{CO}_{2}$ emission to the atmosphere and less use of limited natural resources and thereby more sustainable construction.

\section{References}

Asgeirsson, H., (1986). "Silica fume in cement and silane for counteracting of alkali-silica reactions in Iceland." Cement and Concrete Research, 16(3), 423428.

Bérubé, M. -A. and Duchesne, J., (1992). "Does silica fume merely postpone expansion due to alkaliaggregate reactivity?" In: Proceedings of $9^{\text {th }}$ International Conference on Alkali-Aggregate Reaction in Concrete, 27-31 July, 1992, London, 7180.

Bonavetti, V. L., Rahhal, V. F. and Irassar, E. F., (2001). "Studies of the carboaluminate formation in lime- stone filler-blended cements." Cement and Concrete Research, 31, 853-859.

Collepardi, M., (2007). "Combined use of chemical admixtures and polymer macro-fibres in crack-free industrial concrete floors without wire-mesh." Proceedings of the Jean Péra Symposium on Special Cements and Sustainability Issues, Ed. Kamal $\mathrm{H}$. Khayat, held in conjunction with the $9^{\text {th }}$ CANMET/ACI International Conference on Recent Advances in Concrete Technology, Warszawa, Poland 23-25 May, 2007, 53-65.

De Weerdt K. and Justnes H., (2008). "Microstructure of binder from the pozzolanic reaction between lime and siliceous fly ash, and the effect of limestone addition." RILEM Proceedings PRO 61, Microdurability Conference, Nanjing, 2008, 1, 107-116.

De Weerdt, K., Justnes, H., Kjellsen, K. O. and Sellevold, E., (2010). "Fly ash-limestone ternary composite cements: Synergy effect at 28 days." Nordic Concrete Research, 42(2), 51-70 (ISBN: 97882-8208-023-1).

De Weerdt, K., Sellevold, E., Kjellsen, K.O. and Justnes, H., (2011a). "Fly ash - limestone ternary cements Effect of component fineness." Advances in Cement Research, 23 (4), 203-214.

De Weerdt, K., Ben Ha-Ha, M., Le Saout, G., Kjellsen, K. O., Justnes, H. and Lothenbach, B., (2011b). "Hydration mechanism of ternary Portland cements containing limestone powder and fly ash." Cement and Concrete Research, 41(3), 279-291.

Hirao, H., Yamada, K., Hoshino, S. and Yamashita, H., (2007). "The effect of limestone addition on the optimum sulphate levels of cements having various $\mathrm{Al}_{2} \mathrm{O}_{3}$ contents." Proceedings of the $12^{\text {th }}$ International Congress on Chemistry of Cement (ICCC), 8-13 July 2007, Montreal, Canada.

Hoang, K. D., (2012). “Hardening Accelerator for Fly Ash Blended Cement." Doctoral Thesis at the Norwegian University of Science and Technology (NTNU), Faculty of Engineering Science and Technology, Department of Structural Engineering, Trondheim, Norway, No. 2012:366, 195 pp.

Justnes, H., (1995). "Accelerated hardening of mortars with hydraulic binders of silica fume/lime." Nordic Concrete Research, 17(2) 30-41.

Justnes H., (1996). "Utilization of spent cracker catalyst and lime as hydraulic binders for mortars." Nordic Concrete Research, 19(2) 21-28.

Justnes, H., Elfgren, L. and Ronin, L., (2005). "Mechanism for performance of energetically modified cement versus corresponding blended cement." Cement and Concrete Research, 35, 315-323.

Justnes, H., Dahl, P. A., Ronin, V., Jonasson, J. E. and Elfgren, L., (2007a). "Microstructure and performance of energetically modified cement (EMC) with high filler content." Cement and Concrete Composites, 29, 533-541.

Justnes, H., Ronin, V., Jonasson, J.-E. and Elfgren, L., 
(2007b). "Mechanochemical technology: Energetically modified cements (EMC) with high volume quartz or fly ash." Proceedings of International Conference on Sustainability in the Cement and Concrete Industry, 16-19 September 2007, Lillehammer, Norway, 163-177.

Justnes, H., Ronin, V., Jonasson, J.-E. and Elfgren, L., (2007c), "Mechanochemical technology: Synthesis of energetically modified cements (EMC) with high volume fly ash content." Proceddings of the $12^{\text {th }}$ International Congress on the Chemistry of Cement (ICCC), 8-13 July 2007, Montreal, Canada, paper 84 (TH3-14.4) 12 pp.

Justnes, H., Østnor, T., De Weerdt, K. and Vikan, H., (2011a). "Calcined marl and clay as mineral addition for more sustainable concrete structures." Proceedings of the $36^{\text {th }}$ International Conference on Our World in Concrete \& Structures, 14-16 August 2011, Singapore, 10 pp. (ISBN: 978-981-08-9528-0).

Justnes, H., Østnor, T. and Danner, T., (2011b). "Calcined marl as effective pozzolana." Proceedings of the International RILEM Conference on Advances in Construction Materials Through Science and Engineering, RILEM PRO 79, 5-7 September, 2011, Hong Kong, China, 8 pp.

Kakali G., Tsivilis S., Aggeli E. and Bati M., (2000) "Hydration of the $\mathrm{C}_{3} \mathrm{~A}, \mathrm{C}_{3} \mathrm{~S}$ and Portland cement in the presence of $\mathrm{CaCO}_{3}$." Cement and Concrete Research, 30, 1073-1077.

Kuzel, H. J. and Pöllmann, H., (2001). "Hydration of $\mathrm{C}_{3} \mathrm{~A}$ in the presence of $\mathrm{Ca}(\mathrm{OH})_{2}, \mathrm{CaSO}_{4} \cdot 2 \mathrm{H}_{2} \mathrm{O}$ and $\mathrm{CaCO}_{3}$." Cement and Concrete Research, 21, 885895.

Lee, C. Y., Lee, H. K. and Lee, K. M., (2003). "Strength and microstructural characteristics of chemically activated fly ash-cement systems." Cement and Concrete Research, 33, 425-431.

Lothenbach, B., Le Saout G., Galluci E. and Scrivener K., (2008a). "Influence of limestone on the hydration of Portland cements." Cement and Concrete Research, $38,848-860$.
Lothenbach, B., Matschei, T., Möschner, G. and Glasser, F. P., (2008b). "Thermodynamic modelling of the effect of temperature on the hydration and porosity of portland cement." Cement and Concrete Research, 38, $1-18$.

Matschei, T., Lothenbach, B. and Glasser, F. P., (2007a). "The AFm phases in Portland cement." Cement and Concrete Research, 37, 118-130.

Matschei, T., Lothenbach, B. and Glasser, F. P., (2007b). "The role of calcium carbonate in cement hydration." Cement and Concrete Research, 37, 551-558.

Matschei, T., Lothenbach, B. and Glasser, F. P. (2007c). "Thermodynamic properties of Portland cement hydrates in the system $\mathrm{CaO}-\mathrm{Al}_{2} \mathrm{O}_{3}-\mathrm{SiO}_{2}-\mathrm{CaSO}_{4}$ $\mathrm{CaCO}_{3}-\mathrm{H}_{2} \mathrm{O}$." Cement and Concrete Research, 37, 1379-1410.

Qian, J., Shi, C. and Wang, Z., (2001). "Activation of blended cements containing fly ash." Cement and Concrete Research, 31, 1121-1127.

Rixom, M. R. and Mailvaganam, N. P., (1999). "Chemical admixtures for concrete." 2nd Ed., 1999, Spon Press.

Shi, C. and Day, R. L., (1995). "Acceleration of the reactivity of fly ash by chemical activation." Cement and Concrete Research, 25, 15-21.

Shi, C. and Day, L. R., (2000a). "Pozzolanic reaction in the presence of chemical activators, Part I. Reaction kinetics." Cement and Concrete Research, 30, 51-58.

Shi, C. and Day, L. R., (2000b). "Pozzolanic reaction in the presence of chemical activators, Part II. Reaction products and mechanisms." Cement and Concrete Research, 30, 607-613.

Shi, C. and Day, L. R., (2001). "Comparison of different methods for enhancing reactivity of pozzolans." Cement and Concrete Research, 31, 813-818.

Østnor, T. A. and Justnes, H., (2013). "Durability of mortar with calcined marl as supplementary cementing material." Advances in Cement Research, Available Online 27 September 2013, DOI: 10.1680/ adcr. 13.00040 